\title{
Моніторинг ризику кардіотоксичності у пацієнтів із серцево-судинною коморбідністю в умовах сезону ГРВІ: можливості мельдонію
}

Поєднана соматична патологія характерна для сучасного хворого. Ядром коморбідності, провідними нозологіями, що формують глобальний тягар хвороб, єхвороби системи кровообігу (Амосова Е.Н., 2001; Зербіно Д.Д. та співавт., 2004; Горбась І.М. та співавт., 2005). Європейська політика «Здоров'я для всіх на XXI століття» та Міжнародна програма профілактикинеінфекційнихзахворювань(CINDI) передбачаютьвпровадженняефективнихвисокоякіснихпрофілактичних ілікувально-діагностичнихстратегій, зодного боку, та повнотувивчення явищ, щодосліджуються, івстановлення зв'язків «причина-наслідок» між нозологічними групами - з іншого.

Вагомий пласт досліджень - пошук механізмів імунної відповіді в патогенезі атеросклерозу, ішемічної хвороби серця (IXC) та їх ускладнень. Зокрема зазначаються виражені зміни імунобіологічної реактивності організму, що проявляється підвищеною активністю гуморального імунітету в поєднанні з дефіцитом Т-супресорів (Шевченко О.С., 2005), значущу роль підвищення ліпопротеїдів (ЛП) IgA у хворих із початковими проявами хронічної серцевої недостатності (CH), спричиненої атеросклеротичним імунним запаленням (Рудык Ю.С., Гаргин В.В., 2003).

Як локальне, так і системне запалення, що є характерним для атеросклерозу, мають всі ознаки автоімунного іможуть ініціюватися модифікованими ліпопротеїдами низької щільності (ЛПНЩ) і ліпопротеїдами дуже низької щільності (ЛпДНЩ). Останні набувають автоімунних властивостей і здатні ініціювати імунну відповідь. Розвиток запалення суттєво полегшується завдяки тому, що обом класам ЛПпритаманніхемоатрактантні властивості щодо моноцитів і Т-клітин, що приводить до фокальної адгезії останніх на ендотелії й трансміграції в інтиму (Nilsson J. et al., 1998).

Встановлено, що титр антитіл до окиснених ЛпНЩ підвищений у пацієнтів з ангіографічно верифікованою IXC на $60 \%$ при односудинному ураженні та приблизно у 2 рази більше - при багатосудинному, щоє такожмаркером нестабільностіатеросклеротичної бляшки (АБ) і передвісником розвитку гострих коронарних подій (Inoue T. et al., 2003). Надриви АБ, які призводять до інфаркту міокарда, не обов'язково відбуваються в ділянці максимального стенозування коронарних артерій, а навпаки, часто трапляються в місцях невеликих звужень - менше $50 \%$ за даними ангіографії (Мазур H.A., Швец О.B., 2000; Kirn R.W. et al., 2000).

В останні роки в патогенезі атеросклерозу і клінічному перебігу IXC все більша роль відводиться хронічним інфекціям (Espinila-Klein C. etal., 2002). Клінічними дослідженнями неодноразовопідтверджено, що вплив інфекційного процесу на атеросклероз значною мірою визначається наявністю поєднаного впливу ряду патогенів, а не властивостями будьякого з них. При IXC ендотелій виступає в ролі першочергового органамішені, оскільки ендотеліальне вистилання судин бере участь урегуляції судинного тонусу, гемостазу, імунної відповіді, міграції клітин крові в судинну стінку, синтезі чинників запалення та їх інгібіторів, здійснює бар'єрні функції (Khairy P. et al., 2003; Замбон А., 2006).

При фізіологічному старіннівнаслідокморфофункціональнихзмін ендотелію, змін у нейрогуморальній регуляції розвивається ендотеліальна дисфункція з підтвердженим зниженням рівня NO і простацикліну при одночасному підвищенні рівня ендотеліну-1 і тромбоксану $\mathrm{A}_{2}$; зниження протизапальної активності з відповідним зниженням рівня протизапальних цитокінів та підвищенням рівня адгезивних молекул.

Поки сучасна наука вела дискусію про вплив загального патогенного навантаження хронічних інфекцій на розвиток і прогресування атеросклерозу, визначальною реальністю XXI ст. стало зіткнення неінфекційних та інфекційних епідемій на полі битви проти здоров'я людства. Відповідно, зростання інтересудо проблеми впливугострих респіраторних вірусних інфекцій (ГРВІ) на перебіг хронічних серцевосудинних захворювань (ССЗ) не позбавлене доказового підґрунтя. Так, у ретроспективному аналізі історій хвороб 541 пацієнта з IXC та ГPВІ виявили, що у групі хворих із постінфарктним кардіосклерозом та ГРВІ загострення IXC діагностувалося вдвічі частіше, а гострий інфаркт міокарда виникав утричі частіше порівняно з пацієнтами із постінфарктним кардіосклерозом без супутньої ГРВІ (Жукова Ю.В. и соавт., 2008).

Зростання смертності від IXC було зафіксовано саме у несприятливі щодо ГРВІ пори року. Так, у періоди епідемії грипу щотижневий рівень смертності зростав до 20\%, у періоди епідемії ГРВІ неуточненої етіології- до 12\%. Найвразливішу вікову категорію середчоловіків становили особи віком старше 50 років, середжінокстарші за 60 років (Филиппов А.Е., 2006). Морфологічним підґрунтям таких досліджень є виявлення РНК вірусів грипу (H1N1 та Н3N3) в АБ та, відповідно, забезпеченняпрогресування атеросклерозуякшляхом персистенції даної інфекції в АБ, так і шляхом активації автоімунних механізмів (Плесков В.M. и соавт., 2003; Gurevich V.S. et al., 2005).

у дослідженні J.L. Bouman та співавторів (2002) були продемонстровані прокоагулянтні властивості інфікованих вірусом грипу моноцитів, активація синтезу прозапальних цитокінів, зокрема ІЛ-6 та ІЛ-8, що здатні викликати як локальне, такі системне запалення та ставати причиною розриву АБ. Так само, як хронічні інфекції, ГРВІ здатні транзиторно змінювати функцію ендотелію, що було продемонстровано в дослідженні S. Marchesi (2005), де в популяції здорових чоловіків під час грипу виявлене вірогідне підвищення рівня С-реактивного білка, загального холестерину, тригліцеридів тамолекул адгезії до ендотелію. Дані дослідження стали основою для висновку щодо вірусу грипу як предиктора нестабільності АБ, фактора, що спричиняє ії розрив, утворення тромбу та оклюзії просвіту коронарної артерії. Подальші клінічнідослідження в цьому напрямкупродемонстрували, що ГРВІ у пацієнтів із IXC під час госпіталізації ускладнювали перебіг гострого коронарного синдрому, у тому числі формуючи так звану додаткову смертність (Жукова Ю.В. и соавт., 2008). У зв'язку із цим пошук захисту від ГРВІ в осіб із наявною IXC є надзвичайно актуальним. Проте нове десятиліття XXI ст. сформувало нову проблему появу новихгенерацій вірусів SARS-CoV, SARS-CoV-2, що доклали свій патогенний внесок у дестабілізацію АБ. Серед вивчених механізмів цього процесу сьогодні обговорюються зниження експресії АПФ-2 із дизрегуляцією ренін-ангіотензин-альдостеронової системи, незбалансована відповідь Т-хелперів 1-го та 2-го типу, що забезпечують цитокінову «бурю»; гіпоперфузія, підвищена судинна проникність, ангіоспазм, дихальна дисфункція, підвищення концентрації лізофосфатидилхоліну, лізофосфатидилетаноламіну, фосфатидилгліцерину, вільних жирних кислот (ВЖК). У свою чергу, на тлі високих концентрацій ВЖК (у плазмі крові >1400 нмоль/л) смерть 
виникає протягом 6 год після появи першого больового нападу, що зумовлено пошкоджувальною дією ВЖК на синтез і транспорт АТФ у кардіоміоцитах при ішемії.

Заданими звіту Китайського центру з контролю та профілактики захворювань щодо смертності при COVID-19 та супутній серцевосудинній патології 2019 р., середній коефіцієнт смертностістановив $2,4 \%$, за наявностіартеріальної гіпертензії-6\%, цукрового діабету7,3\%, серцево-судинної коморбідності-10,5\%. Епідеміологічні дані щодо COVID-19 у США продемонстрували різке збільшення кількості госпіталізацій, зокрема до реанімаційних відділень, та смертності у віковому діапазоні 65-74 роки, на який припадає найбільше коморбідне навантаження. Томуувисновкахметааналізу 8 досліджень ( $n=48$ 248) COVID-19 щодо ризиків, асоційованих із SARS-CoV-2 у пацієнтів із серцево-судинною патологією визначено, що наявність ССЗ не асоційована з вищим ризиком зараження коронавірусом, проте, можливо, асоційована з вищим ризиком ускладнень за умов приєднання інфекції. Головними факторами, асоційованими з несприятливим прогнозом, є похилий вік, підвищені рівні D-димеру, високий показник за шкалою SOFA, що включає в ролі одного з оцінюванихіндикаторів рівень середнього артеріального тискуіпотребу у вазопресорній підтримці.

Актуальні умовиперебігухронічних ССЗ приполіморбідностіводночас із запровадженими у XXI ст. заходами у вигляді розширення напрямів застосування препаратів гемодинамічного впливу, усвідомлення їх дозозалежних властивостей, введення ефективних високоякісних профілактичних та лікувально-діагностичних методик (вплив на особливості способу життя та навколишнього середовища, виявлення і зниження рівнів факторів ризику в осіб, схильних до того чи іншого захворювання, запобігання прогресуванню захворювань, їх виявлення на ранніх стадіях) потребують додаткових стратегій енергетичного захисту на клітинному рівні. Сучасні наукові погляди на патогенез IXC та метаболічні порушення в міокарді, що виникають внаслідок ішемії, вимагають зосередити увагу не лише на процесах у коронарних артеріях, але й на процесах, що відбуваються в кардіоміоцитах. Цей підхід особливо актуальний у лікуванні ускладнених форм IXC. Яскравим прикладом цього став феномен «запаморочення від успіхів» - парадоксальногозбільшення кількості пацієнтів із хронічною $\mathrm{CH}$ на тлі успіхів лікування IXC. Одним із головних механізмів розвитку $\mathrm{CH}$ та їі рефрактерності до інотропних впливів $€$ енергодефіцитний стан серця. А розповсюдженапатологія внутрішніх органів додає свій негативний внесок у зниження скоротливої здатності міокарда. Лікарські засоби в таких умовах поліморбідності мають забезпечувати багатовекторний механізм дії, утомучислівплив на загальні ключові патогенетичні ланки захворювань; гармонізацію діяльностіжиттєзабезпечуючихорганіві систем; енергетичний захист на рівні клітинного метаболізму, іонного гомеостазу, впливу на структуру та функцію клітинних мембран; мінімальну побічну дію; комплементарний підхід: хворий - рекомендації.

В умовахсезону ГРВІ особливої уваги потребує моніторинг ризику кардіотоксичності у вигляді обмеження швидкості окиснення ВЖК для більш економного використання кисню; обмеження накопичення ВЖК у мітохондріях, що дозволяє відновити внутрішньоклітинний транспорт і використання АТФ, активації захоплення та окиснення глюкози. До препаратів саме з таким механізмом дії належить мельдоній (препарат Мілдронат $\left.{ }^{\oplus}\right)$ - 3-(2,2,2-триметилгідразиній) пропіонат - структурний аналог природного метаболіту ү-бутиробетаїну. Механізм дії препарату Мілдронат ${ }^{\circledR}$ пов'язаний з інгібуючим впливом на ү-бутиробетаїнгідкроксилазу, у результаті чого порушується розпад ү-бутиробетаїну до карнітину. Це призводить, з одного боку, до зниження рівня карнітину, з другого - до накопичення ү-бутиробетаїнгідроксилази. Зниження рівня карнітину гальмує карнітинзалежний транспорт ВЖК у клітину на 30-40\%. При цьому активується альтернативний механізм енергозабезпечення гліколіз і цикл Кребса. Зниження транспорту ВЖК до клітини в умовах ішеміїперешкоджає руйнації клітинних оболонок, поновлює транспорт АТФ змітохондрій у місця використання, сприяє використаннюхімічно пов'язаного кисню (Карпов Р.С. и соавт., 2000).

Перевагами препарату Мілдронат ${ }^{\circledR}$ порівняно з іншими засобами цитопротекції міокарда є його здатність до стимуляції не тільки глюкози, але й інших сахарів (гексоз), що таким чином сприяє використанню більшої кількості субстратів для отримання енергії. Окиснення препаратом Мілдронат ${ }^{\circledR}$ сахарів не призводить до накопичення молочної кислоти в тканинах, оскільки піруват використовується в циклі трикарбонових кислот. Мілдронат ${ }^{\circledR}$ стимулює Са-АТФазу саркоплазматичного ретикулуму, зменшує зумовлене ішемією зниження концентрації АТФ, АДФ, креатинфосфату і запобігає вираженомупідвищенню вмісту ацетил-Ко-А; здійснює дилатуючий вплив на периферичні та вінцеві артерії та підсилює синергізм інгібіторів АПФ (Дзерве В.Я., Калвиньш И.Я., 2016).

Специфічний вплив цього препарату здатний підвищити толерантність тканин організму до гіпоксії, особливо тканин нирок, головного мозку і скелетних м'язів, гіпоперфузія яких у найвищому ступені зумовлює клінічну симптоматикухронічної СН (Дзерве В. и соавт., 2005). Крім того, відомо, що Мілдронат ${ }^{\circledR}$ сприяє покращенню умов транспорту кисню за рахунок впливу на лігандний спектр гемоглобіну, механічну резистентність еритроцитів і реологічні властивості крові (Сисецкий А.П. и соавт., 1992). Таким чином, Мілдронат ${ }^{\circledast}$ виявляє стимулюючий вплив і на екстракардіальні механізми компенсації гемодинамічних розладів, відповідаючи вимогам до оптимізації лікування коморбіднихпацієнтів, зокрема кількісної мінімалізації фармакологічних засобів з їх поліфармакодинамікою та узгодженості лікувального комплексу з усіма супутніми захворюваннями. Протягом останніх років опубліковані експериментальні дані, згідно з якими карнітин може бути пов'язаний із синтезом проатерогенних метаболітів в організмі (Дамброва М. и соавт., 2014). Кишкові мікроорганізми у процесі метаболізму карнітину синтезують триметиламін (Koeth R.A. etal., 2013), який уподальшому в печінці під впливом флавінзалежної монооксигенази (FMO), окиснюючись, утворює триметиламін-N-оксид(ТМАО). Підвищені концентрації ТМАО пов'язані з розвитком атеросклерозу та ризиком серцево-судинних ускладнень (Liepinsh E. etal., 2011). Мілдронат ${ }^{\circledR}$ знижує якконцентрацію карнітину в плазмі крові людини, такі концентрацію ТМАО, сприяючи виведенню останнього із сечею (Dambrova M. et al., 2013).

Цікавим сегментом ү-бутиробетаїнового механізму препарату Мілдронат ${ }^{\circledR} \epsilon$ забезпечення імунного захисту шляхом нормалізації кількості циркулюючих імунних комплексів, зменшення кількості еозинофілів, зниження вмісту lgE, підвищення вмісту lgA, нормалізацію кількості Т-супресорів та Т-хелперів (Сафронова Л.С. и соавт., 1992). У контексті противірусної вакцинації досліджувалася та була доведена імуноад'ювантна дія цього препарату (Кубарь О.И. и соавт., 1992).

Біохімічними перевагами препарату Мілдронат ${ }^{\circledast} \in$ обмеження транспортучерез мембрани мітохондрій виключно довголанцюгових ЖК; запобігання накопиченню в мітохондріях активованих форм ЖК - ацил-КоА та ацилкарнітину, їх шкідливого впливу на транспорт АТФ і клітинні мембрани; відсутність токсичного впливу на дихання мітохондрій (Калвиньш И.Я., 2001). Ці властивості дозволяють розширити усвідомлення палітри його дії від цитопротекції в широкому сенсі (карнітинінгібуючий механізм) до моніторингу ризику кардіотоксичності (P-FOX-механізм), від вазопротекції (ү-бутиробетаїновий механізм) до тендітних механізмів імунного захисту через біосинтез фізіологічно регульованої кількості NO. А його вплив наАБ, профілактикуї̈ дестабілізації багатогранно реалізується як через інгібіцію окиснення ЖК, так і через зниження концентрації проатерогенного метаболіту ТМАО.

Ті інтелектуальні ресурси, які ми витрачаємо на побудову декількох шляхів досягнення мети, будуть компенсовані відчуттям невразливості та подальшою ефективністю.

Список використаної літератури - www.umj. com.ua

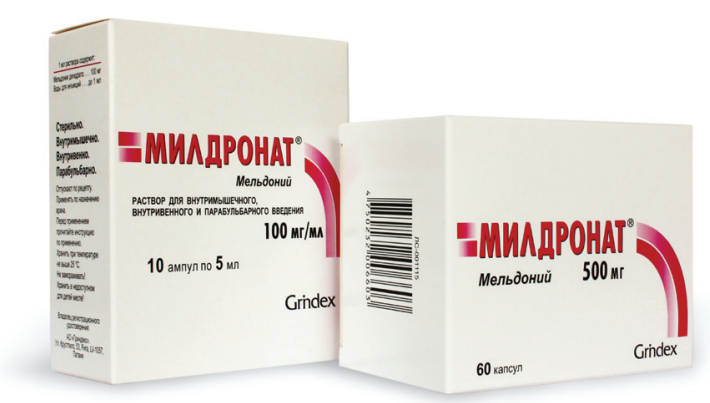

Представництво «АС «Гріндекс" в Україні:

03040, Київ, вул. Красилівська, 11, офіс 3

Тел.: +38 (044) 498-42-32

E-mail: grindeks@ukr.net 